\title{
ANALISIS KANDUNGAN PATI DALAM BATANG TANAMAN AREN (Arenga pinnata)
}

\author{
Jardewig E. Manatar ${ }^{1)}$, Julius Pontoh ${ }^{1)}$, MaxR.J. Runtuwene ${ }^{\text {1) }}$ \\ 1) Program Studi Kimia FMIPA Universitas Sam Ratulangi \\ Jl. Kampus Unsrat Manado, 95115 \\ e-mail : Wiwik_chemis3@rocketmail.com, pontohjulius@yahoo.com,max_runtuwene@yahoo.com,
}

\begin{abstract}
ABSTRAK
Penelitian dilakukan untuk menganalisis kandungan pati dalam batang tanaman aren (Arenga pinnata) dengan caramengetahui variabilitas kandungan pati pada pohon aren di beberapa lokasi yang berbeda di Tomohon dan hubungannya dengan beberapa faktor produktivitas tanaman. Penelitian yang dilaksanakan meliputi pengambilan sampel, pengukuran kadar air, preparasi sampel, pembuatan kurva standar, dan analisis pati. Hasilnya menunjukkan adanya perbedaan kandungan pati pada berbagai posisi di pengaruhi oleh produktivitas dari masing-masing pohon aren dari beberapa lokasi yang berbeda di Tomohon. Kandungan pati yang tertinggi diperoleh sekitar $1 \mathrm{~m}$ di bawah bunga betina pertama pada Posisi 5 bervariasi dari 26-37\%. Kandungan pati diatas $35 \%$ dijadikan indikasi tanaman akan menghasilkan nira yang baik.
\end{abstract}

Kata kunci : A. pinnata, Kandungan Pat.

\section{ANALYSIS OF STARCH CONTENT IN STALK PALM SUGAR PLANT (Arenga pinnata)}

\begin{abstract}
The research do to analyze starch content in stalk palm sugar plant (Arenga pinnata) with to know the variability of starch content in palm sugar plant at some different location in Tomohon and the relationship with some productivity factors of plant. The research activities included starch sampling, measurement of water content, sample preparation, making standard curve and analysis of starch content. The results showed different starch content at various position at a tree and in the trees at various locations in Tomohon. The starch content corelated to the productivity of each palm sugar trees at different location in Tomohon. The highest of starch content found about one meter under first female flower at the fifth position has variation from $26-37 \%$. Starch content above $35 \%$ indicated that tree will produce juice.
\end{abstract}

Keywords : A. pinnata, Starch Content

\section{PENDAHULUAN}

Tanaman aren (Arenga pinnata) dapat menghasilkan nira aren dapat diolah menjadi gula aren. Di Sulawesi Utara, masih banyak petani yang mengolah gula aren karena sangat membantu untuk kehidupan keluarga maupun untuk keperluan masyarakat banyak yang pengolahannya pun tidak sulit. Kandungan pati dalam empulur batang aren akan menentukan jumlah nira yang akan keluar melalui tangkai bunga.Kandungan pati dalam batang pohon aren telah dilaporkan oleh Pontoh (2010). Kandungan pati dalam nira aren bervariasi dari 0.25-0.5 g/g empulur. Faktor yang mempengaruhi produktivitas tanaman aren yaitu tanah, iklim, tanaman meliputi ukuran tanaman dan umur tanaman (Suseno, 1991). Aspek lain dari penentuan kandungan pati dalam empulur pohon adalah cara pengambilan sampel pada pohon (Kunarso, 2008).

\section{TINJAUAN PUSTAKA}

\section{Analisis Pati}

Pati tidak larut dalam air dan dalam analisis pati, memberikan warna biru dengan iodium.Hasil hidrolisis pati/amilum adalah glukosa (Harrow, 1946). 
Hidrolisis pati akan terjadi pada pemanasan dengan asam encer dimana berturut-turut akan dibentuk amilosa yang memberi warna biru dengan iodium, amilopektin yang memberi warna merah dengan iodium. Pati sagu disebut juga poliglukosa, karena unit monomernya glukosa (Anwar, 1994).

\section{Metode Penambahan Iodium}

Penambahan iodium akan terbentuk kompleks pati dan iodium kompleks ini dapat mengendap yang kemudian dapat ditentukan dengan mengukur konsentrasi warna biru yang terbentuk dengan menggunakan spektrofotometer (Wulung, 2008).

Metode ini digunakan untuk memisahkan amilum atau pati yang terkandung dalam larutan tersebut.Reaksi positifnya ditandai dengan adanya perubahan warna menjadi biru.Warna biru yang dihasilkan diperkirakan adalah hasil dari ikatan kompleks antara amilum dengan iodin. Sewaktu amilum yang telah ditetesi iodin kemudian dipanaskan, warna yang dihasilkan sebagai hasil dari reaksi yang positif akan menghilang.Sewaktu didinginkan warna biru akan muncul kembali. (Harrow, 1946).

\section{METODOLOGI PENELITIAN}

\section{Waktu dan Tempat Penelitian}

Penelitian ini dilaksanakan di Laboratorium Teknik Industri, Institut Teknologi Minaesa Tomohon. Waktu pelaksanaan penelitian ini, yaitu selama 4 bulan dari bulan Juli sampai bulan Oktober 2011.

\section{Prosedur Penelitian}

\section{Pengambilan Sampel}

Sampel yang digunakan pada penelitian ini yaitu empulur batang tanaman aren sebanyak 7 pohon di pilih dari empat lokasi yang berbeda di kota Tomohon yaitu Sarongsong, Matani, Kaaten dan Waloan.

\section{Pengambilan Sampel pada Pohon}

Pengambilan sampel adalah dengan memilih titik pengambilan pada pohon yaitu pertama pada bagian bunga betinaselanjutnya diambil $1 \mathrm{~m}$ di bawah bunga betina, titik berikut diambil $1 \mathrm{~m}$ setelah titik di atas demikian seterusnya (Gambar 1). Sampel diambil dengan memakai alat bor yang sudah diberi tali pengikat agar dalam pengambilan sampel, alat bor ini tidak jatuh. Ketika pohon dibor, hasil bor diambil dan diisi dalam kantong plastik yang akan dijadikan sampel.

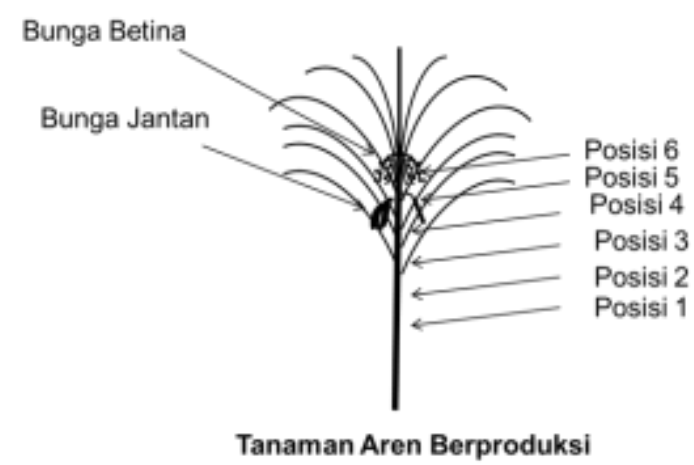

Gambar 1.Tanaman Aren berproduksi

Ket : Posisi 1-6 pada gambar menunjukkan titik pengambilan sampel. Posisi 6 diambil tepat pada bunga betina, posisi 5 diambil $1 \mathrm{~m}$ dibawah bunga betina, selanjutnya diambil pada setiap $1 \mathrm{~m}$ setelah titik di atas demikian seterusnya.

Khusus untuk tanaman A, tanaman ditebang dan di potong-potong sepanjang $1 \mathrm{~m}$. Pati diperoleh dengan menghancurkan empulur dan diekstrak dengan air. Dari tanaman ini diperoleh 6 sampel sesuai dengan jumlah potongan batang. Hal yang sama dilakukan untuk sampel G. Dengan demikian hanya 5 pohon yang sampelnya diambil dengan pengeboran.

\section{Kadar Air}

Sampel ditimbang untuk berat awal $2 \mathrm{~g}$ sampel kemudian dimasukkan kedalam oven bersuhu $105{ }^{\circ} \mathrm{C}$ selama 2 jam, kemudian didinginkan sampai mencapai suhu ruang $27^{\circ} \mathrm{C}$ dan kemudian sampel ditimbang untuk berat akhir sampel. Selanjutnya dihitung kadar air sampel dengan rumus:

$\mathrm{KA}=\frac{(\text { Berat Awal Sampel-Berat Akhir Sampel })}{\text { Berat Awal Sampel }} \times 100 \%$

\section{Preparasi Sampel}

Prosedur kerja ini dilakukan sesuai dengan prosedur Mochtar (1978).

\section{Pemurnian Pati untuk Kurva Standar}

Prosedur kerja ini dilakukan sesuai dengan prosedur Pontoh (2010).

\section{Analisis Pati}

Prosedur kerja ini dilakukan sesuai dengan prosedur Mochtar dan Racman (1978). 


\section{HASIL DAN PEMBAHASAN}

\section{Respon Tanaman terhadap Pengambilan Sampel}

Dari lima tanaman yang diambil sampel dengan pengeboran, dua tanaman mati dan menjadi kering. Tidak diketahui apakah penyebab kematian ini berhubungan langsung dengan pengambilan sampel atau ada faktor lain yang menyebabkannya.

\section{Kurva Standar}

Untuk mendapatkan hubungan antara konsentrasi pati dengan absorbansi pada panjang gelombang $700 \mathrm{~nm}$, telah dilakukan percobaan absorbansi dengan berbagai konsentrasi pati diperoleh kurva standar menunjukkan hubungan yang linier antara absorbansi dengan konsentrasi pati dari 50 ppm sampai 2000 ppm dengan nilai $\mathrm{R} 2=0.997$. Hubungan antara absorbansi dengan konsentrasi mengikuti persamaan linier $\mathrm{Y}=0.000554 \mathrm{X}$.

\section{Kadar Air}

Tabel 1. Kadar Air dalam Sampel

\begin{tabular}{|c|c|c|c|c|c|c|c|c|c|}
\hline Sampel & \multicolumn{10}{|c|}{ Kadar Air Sampel (\%) } \\
\cline { 2 - 11 } & \multicolumn{10}{|c|}{ Posisi } \\
\cline { 2 - 12 } & 1 & 2 & 3 & 4 & 5 & 6 & 7 & 8 & 9 \\
\hline A & 77 & 71 & 64 & 66 & 69 & 80 & & & \\
\hline B & & & 63 & 57 & 56 & 67 & & & \\
\hline C & & & 50 & 49 & 48 & 50 & & & \\
\hline D & & & 71 & 61 & 58 & 48 & & & \\
\hline E & & & 58 & 60 & 57 & 57 & & & \\
\hline F & & & 62 & 55 & 46 & 44 & & & \\
\hline G & 70 & 74 & 76 & 71 & 69 & 74 & 72 & 69 & 70 \\
\hline
\end{tabular}

Ket : A-G menunjukkan nama sampel.

1-9 menunjukkan jarak pengambilan sampel setiap $1 \mathrm{~m}$.

Kadar air dari sampel bervariasi dari 45-80\% (Tabel 1). Kadar air yang rendah diperoleh pada pohon $\mathrm{C}$ dan $\mathrm{F}$ yaitu sekitar $50 \%$ sedangkan kadar air yang tinggi pada pohon A dan G yaitu sekitar 70\%. Terdapat kecenderungan kandungan air pada posisi ke 5 semakin rendah.

\section{Kadar Pati}

\section{Kadar Pati dalam Sampel Kering}

Tabel 2. Persen Kadar Pati dalam Sampel

\begin{tabular}{|c|c|c|c|c|c|c|}
\hline \multirow{2}{*}{ Sampel } & \multicolumn{5}{|c|}{ Kering } \\
\cline { 2 - 7 } & \multicolumn{5}{|c|}{ Posisi } \\
\hline & 1 & 2 & 3 & 4 & 5 & 6 \\
\hline A & 12.9 & 25.5 & 26.3 & 27.9 & 28.0 & 8.6 \\
\hline B & & & 20.7 & 25.1 & 26.2 & 31.2 \\
\hline C & & & 33.6 & 31.5 & 33.2 & 32.6 \\
\hline D & & & 1.1 & 12.2 & 28.1 & 13.4 \\
\hline E & & & 33.1 & 27.1 & 37.0 & 16.6 \\
\hline F & & & 29.1 & 35.2 & 35.5 & 37.1 \\
\hline $\begin{array}{c}\text { Rata- } \\
\text { rata }\end{array}$ & 12.9 & 25.5 & 23.9 & 26.5 & 31.3 & 23.2 \\
\hline
\end{tabular}

Kadar pati merupakan banyaknya pati yang terkandung dalam bahan kering yang dinyatakan dalam persen. Berdasarkan hasil yang didapat untuk sampel pati kering seperti dalam Tabel 2 yang menunjukkan bahwa kadar pati yang tertinggi terdapat pada posisi 5. Posisi 5 berada pada sekitar $1 \mathrm{~m}$ dibawah bunga betina sedangkan posisi 6 berada pada bunga betina. Perbedaan kandungan pati pada berbagai posisi di pengaruhi oleh aktivitas produktivitas dari masing-masing pohon aren. Posisi ke 5 dan 6 merupakan posisi yang paling banyak berhubungan langsung dengan daun tanaman.Pada posisi ke 6 untuk pohon yang telah berproduksi sedikit lebih rendah dari posisi ke 5 disebabkan sebagian pati telah termobilisasi sewaktu terjadi pembungaan, apalagi bila telah disadap niranya secara berulang-ulang.

\section{Kadar Pati dalam Sampel Basah}

Tabel 3. Persen Kadar Pati dalam Sampel

\begin{tabular}{|c|c|c|c|c|c|c|}
\multicolumn{7}{c|}{ Basah } \\
\hline \multirow{2}{*}{ Sampel } & \multicolumn{7}{|c|}{ Kadar Pati Sampel Basah (\%) } \\
\cline { 2 - 7 } & \multicolumn{7}{|c|}{ Posisi } \\
\cline { 2 - 7 } & 1 & 2 & 3 & 4 & 5 & 6 \\
\hline A & 9.93 & 18.29 & 16.94 & 18.51 & 19.38 & 6.90 \\
\hline B & & & 13.16 & 14.32 & 14.93 & 20.91 \\
\hline C & & & 16.90 & 15.61 & 16.20 & 16.62 \\
\hline D & & & 0.54 & 7.19 & 17.30 & 9.51 \\
\hline E & & & 19.20 & 16.40 & 21.28 & 9.61 \\
\hline F & & & 18.05 & 19.63 & 16.52 & 16.70 \\
\hline $\begin{array}{c}\text { Rata- } \\
\text { rata }\end{array}$ & 9.93 & 18.29 & 14.13 & 15.27 & 17.60 & 13.37 \\
\hline
\end{tabular}

Pengaruh kandungan air terhadap kandungan pati dapat dilihat dalam Tabel 3. Sebagaimana dengan kandungan air yang cukup bervariasi dalam tanaman (Tabel 1) menyebabkan variasi kandungan pati dalam keadaan basah. Bila dibandingkan dengan Tabel 2, maka kandungan pati pada tanaman dalam keadaan basah maka kandungan pati dalam tanaman $\mathrm{D}$ sedikit melebihi dari 
tanaman C pada posisi 5 dapat digunakan untuk mengevaluasi kandungan pati tanaman, oleh karena pada posisi ini kandungan pati adalah yang tertinggi.

\section{Kadar Pati dalam Sampel Kering dan Basah pada Sampel (G)}

Tabel 4. Persen Kadar Pati dalam Sampel

Basah dan Kering untuk Sampel (G)

\begin{tabular}{|c|c|c|}
\hline Sampel (G) & \multicolumn{2}{|c|}{ Kadar Pati Sampel (\%) } \\
\hline & Kering & Basah \\
\hline 1 & 0.4 & 0.27 \\
\hline 2 & 0.3 & 0.22 \\
\hline 3 & 0.3 & 0.25 \\
\hline 4 & 0.5 & 0.32 \\
\hline 5 & 0.5 & 0.32 \\
\hline 6 & 0.5 & 0.38 \\
\hline 7 & 0.5 & 0.39 \\
\hline 8 & 0.6 & 0.42 \\
\hline 9 & 0.7 & 0.48 \\
\hline
\end{tabular}

Berdasarkan hasil yang didapat pada Tabel 4, yang menunjukkan kadar pati yang tertinggi untuk sampel $\mathrm{G}$ terdapat pada posisi 9 yaitu $0.7 \%$ dan $0.48 \%$ dan yang paling rendah terdapat pada Posisi 2 yaitu $0,3 \%$ dan $0.22 \%$. Rendahnya kandungan pati pada sampel $\mathrm{G}$ ini, disebabkan oleh tanaman ini sudah sangat tua dan tidak berproduksi lagi.

\section{Hubungan Antara Kandungan Pati dengan Keadaan Pohon}

Keadaan pohon dari suatu sampel sangat berhubungan dengan kandungan pati yang dihasilkan sampel karena faktor pohon yang masih berproduksi dapat menghasilkan pati di dalam batang pohon, sedangkan untuk pohon yang sudah tidak berproduksi, produktivitas kandungan pati pada pohon akan menurun. Tanaman A belum menghasilkan nira, tanaman E, F dan G merupakan tanaman yang telah menghasilkan nira, sedangkan tanaman B, C dan D tidak pernah menghasilkan nira.

\section{KESIMPULAN}

Dari hasil penelitian ini maka dapatlah disimpulkan bahwa kandungan pati dalam batang tanaman aren sangat bervariasi antara pohon dari beberapa lokasi yang berbeda di Tomohon dan dari posisi pada batang tanaman.Kandungan pati yang tertinggi diperoleh sekitar $1 \mathrm{~m}$ dibawah bunga betina pertama pada yaitu pada Posisi 5 yang bervariasi dari 26-37 \%.Sampel F memiliki kandungan pati yang tertinggi dimana induk tanaman masih menghasilkan nira.
Kandungan pati yang terendah di bawah 26 $\%$ terdapat pada Posisi 2 pada sampel G dimana induk tanaman ini sudah tidak menghasilkan nira. Kandungan pati diatas 35 $\%$ dapat dijadikan indikasi bahwa tanaman akan menghasilkan nira yang baik.

\section{DAFTAR PUSTAKA}

Anwar, C. 1994. Pengantar Praktikum Kimia Organik. Depdikbud Dirjen Pendidikkan Tinggi : Yogyakarta.

Harrow, B. 1946. Textbook of Biochemistry. London: W. B. Saunder Company.

Kunarso. 2008. Kepala UPTD-P2BP Disbun Provinsi Kalimantan Timur, Sekretaris Pokja Bidang Perkebunan Komda Plasma Nutfhah.Provinsi Kalimantan Timur.14-12-2008.

Mochtar, M. dan A. Rachman.1978. Penentuan Analisis Teknologi Gula di Experimental Plant BP3G Pasuruan.Pasuruan.

Pontoh, J. 2010. Laporan Pada Yayasan Masarang. Tomohon : Institut Teknologi Minaesa.

Suseno, S. 1991. Berkebun Aren. PT Penebar Swadaya. Jakarta.

Wulung, R.B. 2008.”Petunjuk Praktikum Kimia Organik". Akademi Teknologi Kulit:Yogyakarta. 